\title{
Fine Root Hydraulic Conductance Is Related to Post-transplant Recovery of Two Quercus Tree Species
}

\author{
Jingjing Yin, Nina L. Bassuk, Madeline W. Olberg, and Taryn L. Bauerle ${ }^{1}$ \\ Department of Horticulture, Cornell University, 134A Plant Science Building, Ithaca, NY 14853
}

\begin{abstract}
AdDitionAL INDEX wORDs. fine root branch morphology, Quercus bicolor, Quercus macrocarpa, transplant shock, transplant timing, tree transplant size

ABSTRACT. In our study, we investigated whether root hydraulic conductance is related to post-transplant recovery. We used two Quercus species that differ in their transplant ability, Q. bicolor and $Q$. macrocarpa. $Q$. bicolor easily survives transplanting, whereas $Q$. macrocarpa often does not. We compared root hydraulic conductance after transplanting between control (without root pruning) and root-pruned, 1-year-old, small-caliper trees. We also examined the effects of transplant timing on post-transplant recovery of large-caliper trees. Hydraulic conductance in fine roots was correlated with recovery of the two Quercus species after transplanting. Six months after transplanting, small-caliper $Q$. bicolor trees had similar specific hydraulic conductance $\left(K_{S}\right)$ in fine roots compared with the $K_{S}$ before root-pruning, whereas fine root $K_{S}$ in small-caliper $Q$. macrocarpa trees decreased. Lower pre-dawn and midday xylem water potential in root-pruned $Q$. macrocarpa 6 weeks after transplanting indicates that root-pruned $Q$. macrocarpa experienced transplanting-induced water stress. For large-caliper trees, all $Q$. macrocarpa trees exhibited typical symptoms of transplant shock regardless of transplant timing, which was the result of higher vulnerability to mild water stress compared with $Q$. bicolor, resulting in a large reduction in fine root $K_{\mathrm{S}}$. Fine root $K_{\mathrm{S}}$ in springtransplanted $Q$. bicolor trees was much higher than that in fall-transplanted trees, implying spring transplanting is optimal for $Q$. bicolor. Other intrinsic characteristics of the species should be considered in the future when making better decisions on transplant timing such as xylem anatomy, carbon storage, rhizosphere conditions, and plant growth.
\end{abstract}

Survivorship of high-quality landscape field-grown trees is a particular challenge as a result of differences in post-transplant recovery between species. During bare-root tree transplanting, a major part of the root system is severed, the tree is held in storage, and then replanted into a new location. Not surprisingly, the loss of a large proportion of biomass usually results in major physiological changes within the tree until an adequate root system is rebuilt. Meanwhile, poor root-soil contact resulting from the loss of a majority of fine roots (the sites of water and nutrient uptake) often results in water stress in newly transplanted trees (Grossnickle, 1988). This large loss of plant biomass coupled with exposure to dry conditions is referred to as "transplant shock," in which a plant shows less shoot growth, smaller "scorched" new leaves, and a general lack of vigor (Watson and Himelick, 1983).

Root hydraulic conductance describes the ability of roots to take up water from a growing medium and transport the water to other parts of a tree. Water stress during transplant shock greatly disrupts normal water transport capacity of a tree. Under drought, reduced xylem water potential may cause embolisms, air-filled xylem conduits, leading to a reduction in hydraulic conductance $[K$ (the mass flow rate through the segment divided by the pressure difference)] (Schultz and Matthews, 1988; Sperry and Saliendra, 1994) and thus transpiration (Sperry and Pockman, 1993). Root $K$, as a major component of whole-tree hydraulic architecture (Cruiziat et al., 2002), has been neglected in previous studies despite its reduction at

Received for publication 17 July 2014. Accepted for publication 10 Sept. 2014. We thank Pat MacRae for help in transporting large-caliper trees from the nursery to Bluegrass Lane research field in Ithaca, NY.

${ }^{1}$ Corresponding author. E-mail: bauerle@cornell.edu. transplanting and its probable influence on post-transplant recovery. Hydraulic conductance of the entire root system of Corylus colurna was reported to be reduced significantly after transplanting (Harris and Bassuk, 1995). Regarding trees, transpiration pulls water from soil to leaves and to the atmosphere and creates a variable gradient of water potential throughout the tree. Water potential distribution along the root system is thus very dependent on root architecture such as fine root and coarse root branching (Cruiziat et al., 2002). This makes it reasonable to assume fine roots and coarse roots may have different hydraulic responses during transplant shock and may play different roles in post-transplant recovery.

Transplant timing is important in post-transplant recovery. Spring and fall are usually considered to be the appropriate times for temperate tree transplanting, but the question about which season is optimal is highly disputable. The major advantage of fall transplanting is to allow root regeneration before shoot growth in the spring and provide more time for roots to acclimate to the new soil environment, whereas spring provides ample soil moisture and allows transplanted trees to avoid cold weather (Richardson-Calfee et al., 2004). However, species vary in their survival as a function of transplant seasons (Harris et al., 2002). Fine root traits, including physiology and morphology, largely determine maximum potential growth rate of tree seedlings (Comas et al., 2002). By understanding the physiological basis of root behavior during fall vs. spring transplanting, better decisions regarding transplant timing can be made.

Tree transplant size may affect post-transplant recovery. Although large-caliper trees are often more desired to produce an immediately mature landscape, it was often found that largecaliper trees have a slower growth rate than small-caliper trees 
(Gilman et al., 1998). After root pruning, the artificial imbalance in the proportion of roots to shoots reduces vigor for a period of time with small-caliper trees often returning to the original shoot-to-root ratio sooner and thus having higher survival rates (Watson, 1985). However, there are some factors that may affect the rate of post-transplant recovery of smalland large-caliper trees that when accounted for can increase large-caliper tree recovery to a similar rate as small-caliper trees. For example, genetic variation between small- and largecaliper trees has often been overlooked: the more vigorous trees tend to be harvested at smaller caliper sizes in nursery production practices because they are the first to reach salable size and thus the last ones harvested from a nursery block are usually slower-growing large-caliper trees, which may be genetically inferior to the earlier harvests (Struve, 2009; Struve et al., 2000).

In this study, we used two Quercus species that differ in their transplant ability, Q. bicolor and Q. macrocarpa. Although these species are closely related, $Q$. bicolor easily survives transplanting, whereas Q. macrocarpa often does not (Buckstrup and Bassuk, 2009). We transplanted both small- and large-caliper trees of the two species and examined $K$ before and after transplanting in fine roots, coarse roots, and the entire root system of the trees. Additionally, we assessed how transplant timing affected post-transplant recovery in large-caliper trees. The objective of this study was to determine whether root $K$ is related to post-transplant recovery of the two Quercus species and whether tree size and transplant timing may affect transplant recovery.

\section{Materials and Methods}

SMall-CALIPER TREe Material AND EXPERIMENTAL DESIGN. Twelve bare-root 1-year-old Q. bicolor and 12 Q. macrocarpa trees ( $8 \mathrm{~mm}$ caliper; Lawyer Nursery, Plains, MT) were planted in \#3 containers (11.3 L; Hydrofarm, Fairless Hills, PA) containing Pro Mix soilless media (70\% peatmoss and $25 \%$ perlite soilless media; Premier Tech, Mississauga, Ontario, Canada) in Spring 2012 and grown in an unheated polyhouse at Cornell University in Ithaca, NY (lat. $42.48^{\circ} \mathrm{N}$, long. $76.47^{\circ} \mathrm{W}$, elevation $335 \mathrm{~m}$ ). The temperature, humidity, and light intensity in the greenhouse were similar to seasonal growing conditions. In Mar. 2013, the trees were brought into the greenhouse where the temperature was maintained at $24{ }^{\circ} \mathrm{C}$ during the day and $18{ }^{\circ} \mathrm{C}$ during the night for the whole experimental time. The trees were well-watered daily from Mar. 2013 to Oct. 2013 and fertilized with $15 \mathrm{~N}-2.2 \mathrm{P}-12.5 \mathrm{~K}$ water-soluble fertilizer (Peters Excel 15-5-15 CalMag; Scotts Co., Marysville, $\mathrm{OH}$ ) twice per week for 1 month before the experiment was initiated in Apr. 2013.

In Apr. 2013, the trees were brought into the laboratory. For each Quercus species, six trees were randomly selected as controls (no root pruning treatment) and the other six trees of each species were randomly selected to undergo a simulated transplant treatment. The treatment trees were removed from their containers, pruned $\approx 80 \%$ of the entire root system from the bottom and sides of the root ball, and allowed to dry on the laboratory bench covered by a thin layer of the soilless media they were growing in for $3 \mathrm{~d}$ before returning them to their original containers with the former soilless media. The laboratory environmental conditions were maintained at $\approx 20^{\circ} \mathrm{C}, 30 \%$ relative humidity, and a photoperiod of $\approx 12 / 12 \mathrm{~h}$ (light/dark).
The treatment trees were returned to the greenhouse immediately after the treatment with control trees. Locations of the trees within the greenhouse were randomly assigned. Tree locations were re-randomized every 2 weeks to minimize location effects.

Root hydRaulic CONDUCTANCE MEasurement. Before the 3-d drying period in Apr. 2013, three fine root branches were randomly collected from all control and treatment trees for hydraulic conductance measurements using a hydraulic conductance flow meter [HCFM (Gen 3; Dynamax, Houston, TX)]. The length of the fine root branch was $\approx 20 \mathrm{~cm}$, and the diameter of the highest order roots (fourth order roots; Pregitzer et al., 2002) on the branch was $\approx 1.5$ to $2.0 \mathrm{~mm}$. Immediately before measurement, the end of the branch was re-cut off under water with a sharp blade resulting in the branch that was $\approx 15 \mathrm{~cm}$ long. Hydraulic conductance in fine root branches was measured with the transient measurement mode, which rapidly increased the applied pressure and simultaneously measured the corresponding flow (Tyree et al., 1995). Degassed deionized water was forced through the root branches under increasing pressure until the pressure reached $500 \mathrm{kPa}$. The instantaneous flow and pressure were recorded every 2 s. Hydraulic conductance $\left(\mathrm{kg} \cdot \mathrm{s}^{-1} \cdot \mathrm{kPa}^{-1}\right)$ was calculated from the slope of linear regression between the pressure and flow. The diameter of each fourthorder root was measured using a digital caliper to calculate specific hydraulic conductance $\left(\mathrm{kg} \cdot \mathrm{s}^{-1} \cdot \mathrm{m}^{-2} \cdot \mathrm{kPa}^{-1}\right), K$ divided by cross-sectional area of the root. Root pruning was conducted on the treatment trees immediately after the $K$ measurement. For control trees, $K$ was measured at the same time as root pruned trees and the trees were immediately placed back into the containers with old soilless media. Stem diameter of all trees was measured using a digital caliper $5 \mathrm{~cm}$ above the root collar.

All of the trees were harvested in Oct. 2013. Hydraulic conductance was measured again on three fine root branches as described previously and on entire root systems for each tree using the HCFM. Shoots (including stem and leaves) were cut off $\approx 5 \mathrm{~cm}$ above the root collar. Stem diameter of all trees was measured again with a digital caliper at the cutting end, and stem diameter growth between Apr. 2013 and Oct. 2013 was calculated. To measure $K$ of the entire root system, the root system was left in the soil and the root stump was immediately re-cut under water to avoid cavitation. The remaining root stump was connected to HCFM and $K$ of the entire root system was measured as described previously as fine roots. All leaves were removed from stems and scanned using a leaf area meter (LI-3100; LI-COR, Lincoln, NE) to determine total leaf area of each tree. Leaf area was used to calculate leaf area-specific hydraulic conductance $\left[K_{\mathrm{L}}\left(\mathrm{kg} \cdot \mathrm{s}^{-1} \cdot \mathrm{m}^{-2} \cdot \mathrm{kPa}^{-1}\right)\right]$, total root system $K$ divided by total leaf area, of root systems.

Vulnerability CuRVes. Three trees per species from the non-root-pruned treatment were sampled to determine vulnerability curves using the centrifuge technique described in Alder et al. (1997). In brief, an unbranched stem segment (generally at the base of the tree), $\approx 20 \mathrm{~cm}$ in length, was cut from each tree and re-cut to $14 \mathrm{~cm}$ under water before measurement. The stem segment was first flushed with degassed deionized water for 30 min at $\approx 350 \mathrm{kPa}$ to remove native embolisms. The maximum hydraulic conductivity $\left[k_{\max }\left(\mathrm{kg} \cdot \mathrm{m} \cdot \mathrm{s}^{-1} \cdot \mathrm{MPa}^{-1}\right)\right]$ of the stem segment was measured using the gravity method described in Sperry et al. (1988). Gravity-induced flow of deionized water containing $20 \mathrm{~mm} \mathrm{KCl}$ was applied to the segment with a pressure of 6 to $7 \mathrm{kPa}$. The solution was degassed before 
use by agitating it vigorously with a magnetic stirrer for $\approx 45$ min under vacuum (Sperry and Tyree, 1990). For each measurement, hydraulic conductivity $\left[k\left(\mathrm{~kg} \cdot \mathrm{m} \cdot \mathrm{s}^{-1} \cdot \mathrm{MPa}^{-1}\right)\right]$ was calculated every $10 \mathrm{~s}$ as the mass flow rate of solution through the stem segment divided by the pressure gradient along the segment together with a $\mathrm{CV}$ of the previous 10 readings. When the $\mathrm{CV}$ was less than $0.3 \%$, we averaged the last three readings as the conductivity for the stem segment. The measurement time for one stem segment was $\approx 15$ to $20 \mathrm{~min}$.

The stem segment was then spun in a centrifuge (RC5G Plus; Thermo Fisher Scientific, Waltham, MA) with a custom-built centrifuge rotor to generate a given negative xylem pressure. The xylem pressure generated was $-0.5,-1.0,-1.5,-2,-3$, and $-4 \mathrm{MPa}$, which was adjusted by varying the rotational velocity (Alder et al., 1997). Stem $k$ was decreased with increasing negative xylem pressure. The percentage loss of hydraulic conductivity (PLC) was calculated as:

$$
\mathrm{PLC}=100 \times\left(k_{\max }-k\right) / k_{\max }
$$

The curve of PLC vs. xylem pressure was then plotted. Each PLC curve was fitted with a second-order polynomial model. The polynomial models were used to calculate the pressure potential at $50 \%$ loss of conductivity $\left(P_{50}\right)$ for each species separately.

SOIL-TO-LEAF HYDRAUlic CONDUCTANCE MEASUREMENT. Six weeks after transplanting, pre-dawn $\left[\Psi_{\text {pre }}(\mathrm{MPa})\right]$ and midday leaf xylem water potential $\left[\Psi_{\text {mid }}(\mathrm{MPa})\right]$ was measured on the trees growing in the greenhouse using a pressure chamber (3005F01; Soilmoisture Equipment Corp., Santa Barbara, CA). Immediately before measuring $\Psi_{\text {mid }}$, midday transpiration rate $\left[E\left(\mathrm{mmol} \cdot \mathrm{s}^{-1} \cdot \mathrm{m}^{-2}\right)\right]$ was measured on the same leaf using a portable photosynthesis system (CIRAS-2; PP Systems, Amesbury, MA). The measurements were conducted on two fully developed leaves of each tree once every 6 weeks until Sept. 2013. Soil-to-leaf $K\left[K_{\mathrm{P}}\left(\mathrm{mmol} \cdot \mathrm{s}^{-1} \cdot \mathrm{m}^{-2} \cdot \mathrm{MPa}^{-1}\right)\right]$ was then calculated as:

$$
K_{\mathrm{P}}=\frac{E}{\left(\Psi_{\text {pre }}-\Psi_{\text {mid }}\right)}
$$

EXPERIMENT ON LARGE-CALIPER TREES. Large-caliper (40-mm caliper) $Q$. bicolor and $Q$. macrocarpa bare-root trees were obtained from Schichtel's Nursery in Springville, NY, and bareroot transplanted at Bluegrass Lane research field in Ithaca, NY, in either early Nov. 2012 or late Apr. 2013. The trees were produced from seed and grown in the nursery for 3 years before transplanting to the Ithaca research field. Tree root systems were dug by undercutting the roots with a "U" blade. Trees were wrapped with a large plastic bag during transport. All of trees were growing together in an Arkport sandy loam at the Bluegrass Lane research field. The location of each tree in the field was randomly assigned. The trees were watered weekly with $20 \mathrm{~L}$ of water starting immediately after transplanting in November and then again in April through September.

Hydraulic conductance was measured on fine roots $(\approx 1.5$ to $2 \mathrm{~mm}$ in diameter) of three fall-transplanted trees in each Quercus species before transplanting in early Nov. 2012. Three fine roots of $\approx 20$ to $25 \mathrm{~cm}$ in length were collected randomly from the root system of each tree, wrapped in moist paper towels, sealed in a plastic bag, and moved to the laboratory in a cooler. In the laboratory, the fine root segments were re-cut under water to a length of $15 \mathrm{~cm}$, and $K$ was measured with the HCFM as described previously for roots from small-caliper trees. After the measurement, root diameters were measured using a digital caliper to estimate $K_{\mathrm{S}}$. In late Apr. 2013, $\approx 6$ months after transplanting, fine root $K$ was measured on three fine roots of the same trees with the same method. In addition, two coarse roots ( $\approx 3$ to $5 \mathrm{~mm}$ in diameter) were also collected from each tree and used to measure coarse root $K$ and estimate coarse root $K_{\mathrm{S}}$. For each tree, both fine roots and coarse roots were excavated from randomly selected locations 20 to $30 \mathrm{~cm}$ away from the root collar of the tree using shovels and trowels. If soil was adhering to the lower-order roots, it was left on the roots during transport and $K$ measurement to minimize root damage.

For spring-transplanted trees, $K$ was measured on three fine roots and two coarse roots of three trees for each species before transplanting in late Apr. 2013 and in early Oct. 2013, 6 months after transplanting using the methods described for fall-transplanted trees.

Fine root MORPhology. While collecting fine roots for $K$ measurement in Apr. 2013, another fine root branch was randomly collected from each of three fall-transplanted largecaliper trees per species as described previously. The length of the fine root branches was $\approx 20$ to $25 \mathrm{~cm}$, and the highest root order of the branches was fifth order, $\approx 2.0$ to $2.5 \mathrm{~mm}$ in diameter. Once collected, the fine root branches were sealed in plastic bags and transported to the laboratory in a cooler.

In the laboratory, remaining soil adhering to the fine root branches was carefully removed under water and the number of roots in each order was counted. The logarithm of the number of roots in each order was then regressed on root order, and the antilog of the absolute value of the slope was calculated as the branching ratio $\left(R_{\mathrm{b}}\right)$ of the fine root branch (Fitter, 1982).

Statistical anAlysis. For small-caliper trees, Tukey's honest significant difference (HSD) test was used to compare the differences among means $(n=6)$ of initial stem diameter, stem diameter growth between Apr. 2013 and Oct. 2013, root system $K$ and $K_{\mathrm{L}}$, and $\Psi_{\text {pre }}$ and $\Psi_{\text {mid }}$ on each measurement date across the combinations of species and treatment. The means of each pair was compared using Student's $t$ test. Two-way analysis of variance (ANOVA) was used to test the effects of root pruning treatment and measurement date and their interactions on fine root $K_{\mathrm{S}}$ and $K_{\mathrm{P}}$ within each species. A repeated-measures ANOVA was conducted to compare PLC across a variety of xylem water potential. Student's $t$ test was used to compare $P_{50}$ calculated from each second-order polynomial model between two species. Data were tested for normality. Fine root $K_{\mathrm{S}}$ was $\log _{10}$-transformed before analyses. The correlation between $K_{\mathrm{S}}$ in fine roots and stem diameter growth between Apr. 2013 and Oct. 2013 across all species and treatments was evaluated using Spearman rank correlation.

For large-caliper trees, Tukey's HSD test was used to compare the means $(\mathrm{n}=3)$ of $K_{\mathrm{S}}$ in fine roots and coarse roots of either fall- or spring-transplanted trees across the combinations of species and measurement date. The means of $K_{\mathrm{S}}$ within the species were compared using Student's $t$ test. Coarse roots were not sampled from fall-transplanted trees before transplanting, so coarse root $K_{\mathrm{S}} 6$ months after transplanting was compared between two species using Student's $t$ test. Student's $t$ test was also used to compare the means of $R_{\mathrm{b}}$ and the number of each root order between two species. Differences among means were 
considered significant if $P \leq 0.05$. All statistical analyses were performed in JMP Pro (Version 9.0.3; SAS Institute, Cary, NC).

\section{Results}

SMALl-CALIPER TREeS. Both small-caliper $Q$. bicolor and Q. macrocarpa trees survived transplanting and did not exhibit any symptoms of transplant shock. $Q$. bicolor had larger stem diameter than $Q$. macrocarpa when the experiment was initiated (Table 1). During Apr. 2013 and Oct. 2013, stem

Table 1. The means $(n=6)$ of initial stem diameter, stem diameter growth, root system hydraulic conductance $(K)$, and leaf-area specific hydraulic conductance $\left(K_{\mathrm{L}}\right)$ of control and root-pruned small-caliper Quercus bicolor and Quercus macrocarpa trees. ${ }^{z}$

\begin{tabular}{lccccc}
\hline & \multicolumn{2}{c}{ Q. bicolor } & & \multicolumn{2}{c}{ Q. macrocarpa } \\
\cline { 2 - 3 } & Control & $\begin{array}{c}\text { Root } \\
\text { pruning }\end{array}$ & & Control & $\begin{array}{c}\text { Root } \\
\text { pruning }\end{array}$ \\
\hline $\begin{array}{l}\text { Initial stem diameter } \\
(\mathrm{mm})\end{array}$ & $7.68 \mathrm{a}^{\mathrm{y}}$ & $7.87 \mathrm{a}$ & & $4.94 \mathrm{~b}$ & $5.75 \mathrm{~b}$ \\
$\begin{array}{l}\text { Stem diameter growth } \\
(\mathrm{mm})\end{array}$ & $7.78 \mathrm{a}$ & $5.38 \mathrm{~b}$ & & $4.89 \mathrm{~b}$ & $2.43 \mathrm{c}$ \\
$\begin{array}{l}\text { Root system } K \\
\left(10^{-7} \mathrm{~kg} \cdot \mathrm{s}^{-1} \cdot \mathrm{kPa}^{-1}\right)\end{array}$ & $1.35 \mathrm{a}$ & $1.12 \mathrm{a}$ & $0.38 \mathrm{~b}$ & $0.25 \mathrm{~b}$ \\
$\begin{array}{l}\text { Root system } K_{\mathrm{L}} \\
\left(10^{-5} \mathrm{~kg} \cdot \mathrm{s}^{-1} \cdot \mathrm{m}^{-2} \cdot \mathrm{KPa}^{-1}\right)\end{array}$ & $4.40 \mathrm{a}$ & $4.57 \mathrm{a}$ & $1.55 \mathrm{~b}$ & $1.10 \mathrm{~b}$
\end{tabular}

${ }^{\mathrm{z}}$ Measurements were taken 6 months after transplanting in Oct. 2013. ${ }^{y}$ Different lowercase letters within the same row indicate significant differences between the means $(\mathrm{n}=6)$ according to Tukey's honestly significant difference test $(P \leq 0.05)$.

Table 2. The means $(n=6)$ of fine root-specific hydraulic conductance $\left(K_{\mathrm{S}}\right)$ of control and root-pruned small-caliper Quercus bicolor and Quercus macrocarpa trees. $^{\mathrm{z}}$

\begin{tabular}{lllc}
\hline Species & Treatment & Date & $\begin{array}{c}\text { Fine root } K_{\mathrm{S}} \\
\left(10^{-3} \mathrm{~kg} \cdot \mathrm{s}^{-1} \cdot \mathrm{m}^{-2} \cdot \mathrm{kPa}^{-1}\right)\end{array}$ \\
\hline Q. bicolor & Control & April & $2.33 \mathrm{a}^{\mathrm{y}}$ \\
& October & $2.36 \mathrm{a}$ \\
& Root pruning & April & $3.01 \mathrm{a}$ \\
& October & $2.59 \mathrm{a}$ \\
& Statistical & & \\
& significance & & \\
& Treatment & & 0.146 \\
& Date & & 0.520 \\
& Treatment $\times$ date & & 0.997 \\
& & & \\
& Control & April & $2.89 \mathrm{a}$ \\
& October & $1.53 \mathrm{~b}$ \\
& Root pruning & April & $2.97 \mathrm{a}$ \\
& Statistical & & $0.36 \mathrm{c}$ \\
significance & & \\
Treatment & & $<\mathbf{0 . 0 0 1}$ \\
Date & & $\mathbf{0 . 0 1 3}$ \\
Treatment $\times$ date & & $\mathbf{0 . 0 1 1}$ \\
\hline
\end{tabular}

${ }^{\mathrm{z}}$ Measurements were taken immediately before transplanting in Apr. 2013 and 6 months after transplanting in Oct. 2013.

${ }^{y}$ Different lowercase letters within the same species indicate significant differences between the means $(\mathrm{n}=6)$ according to Tukey's honestly significant difference test $(P \leq 0.05)$.

xThe values of $P \leq 0.05$ are indicated with bold typeface. diameter growth in root-pruned $Q$. bicolor was smaller than its controls by $\approx 45 \%[P=0.019$ (Table 1 )], whereas the increase in stem diameter of root-pruned $Q$. macrocarpa was $\approx 101 \%$ smaller than its controls $(P<0.001)$.

Small-caliper $Q$. bicolor and $Q$. macrocarpa had similar $K_{\mathrm{S}}$ in fine roots before root pruning [0.002 to 0.003 $\mathrm{kg} \cdot \mathrm{s}^{-1} \cdot \mathrm{m}^{-2} \cdot \mathrm{kPa}^{-1}$ (Table 2)]. Six months after root pruning, $K_{\mathrm{S}}$ in both control and root-pruned $Q$. bicolor was similar to pre-treatment values. In contrast, $K_{\mathrm{S}}$ in both control and root-pruned Q. macrocarpa declined between Apr. 2013 and Oct. 2013. Specifically, $K_{\mathrm{S}}$ in control $Q$. macrocarpa declined by $89 \%(P=0.023)$, whereas $K_{\mathrm{S}}$ in root-pruned $Q$. macrocarpa was $725 \%$ lower than the pre-treatment $(P<$ $0.001)$. Trees with higher fine root $K_{\mathrm{S}} 6$ months after transplanting tended to have larger stem diameter growth with the Spearman rank correlation coefficient between fine root $K_{\mathrm{S}}$ and stem diameter growth being $0.65[P<0.001$ (Fig. 1)].

In Oct. 2013, root system $K$ and $K_{\mathrm{L}}$ was greater in $Q$. bicolor than $Q$. macrocarpa (Table 1). Root pruning had no effect on $K$ or $K_{\mathrm{L}}$ in either species.

Six weeks after transplanting, $K_{\mathrm{P}}$ in $Q$. bicolor trees was higher than that in $Q$. macrocarpa trees in both the control and root pruning treatment groups $[P<0.001$ for both (Fig. 2)]. However, the difference in $K_{\mathrm{P}}$ between controls and rootpruned trees was similar between the two species. Twelve weeks after transplanting, root pruning had no effect on $K_{\mathrm{P}}$, and $K_{\mathrm{P}}$ was similar for both species. Eighteen weeks after transplanting, in Fall $2013, K_{\mathrm{P}}$ in both species was reduced compared with the $K_{\mathrm{P}}$ in the summer despite the treatment. The decline in root-pruned $Q$. macrocarpa was more marked ( $83 \%$ of its summer $K_{\mathrm{P}}$ compared with the reduction of $55 \%$ of

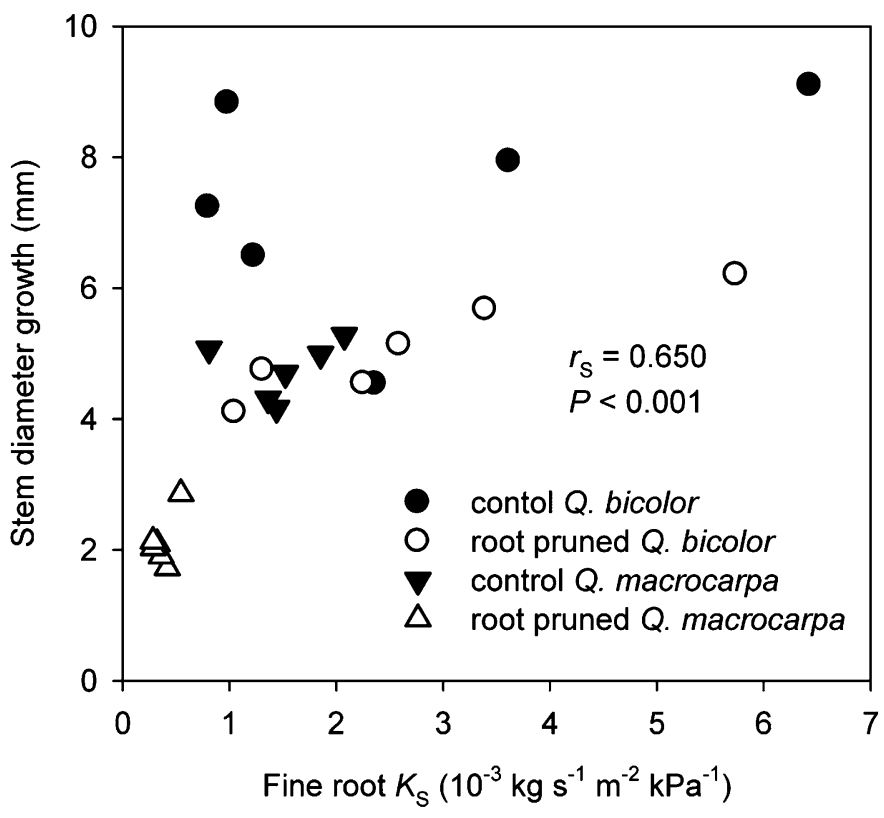

Fig. 1. Relationship between specific hydraulic conductance $\left(K_{\mathrm{S}}\right)$ in fine roots one growing season after transplanting and stem diameter growth between Apr. 2013 and Oct. 2013. Solid dots represent control (without root pruning) Quercus bicolor; open dots represent root-pruned $Q$. bicolor; solid triangles represent control Quercus macrocarpa; open triangles represent root-pruned Q. macrocarpa. Spearman rank correlation coefficient $\left(r_{\mathrm{S}}\right)$ and level of significance of probability value are indicated. 

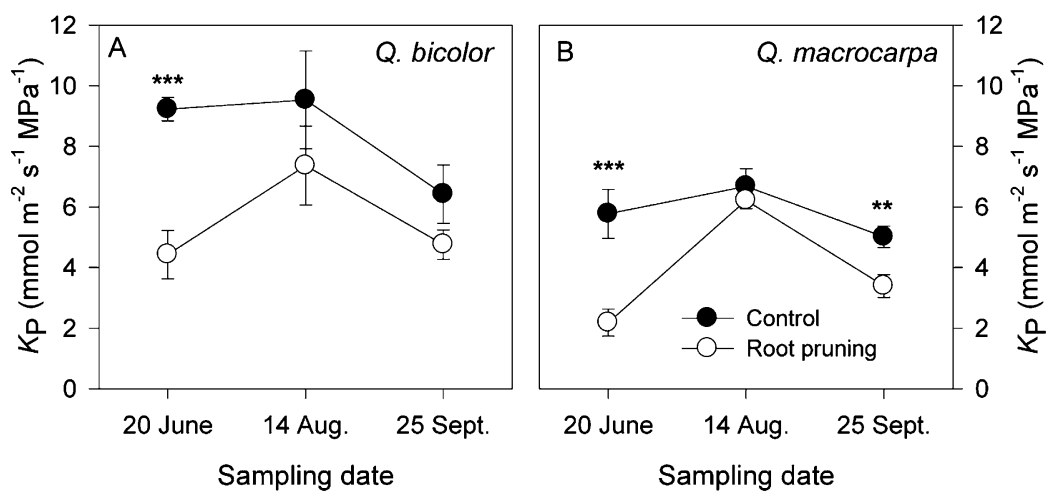

Fig. 2. Variation of soil-to-leaf hydraulic conductance $\left(K_{\mathrm{P}}\right)$ for control (solid dots) and root-pruned (open dots) small-caliper Quercus bicolor (A) and Quercus macrocarpa (B) trees 6 weeks (20 June), 12 weeks (14 Aug.), and 18 weeks (25 Sept.) after transplanting during the growing season. Measurements were taken three times during the growing season. $* * *, * *$, and $*$ indicate difference was significant at $P=0.001, P=0.01$, and $P=0.05$, respectively, according to Tukey's honestly significant difference test.

Table 3. Pre-dawn $\left(\Psi_{\text {pre }}\right)$ and midday $\left(\Psi_{\text {mid }}\right)$ xylem water potential $(\mathrm{n}=6)$ of control and root-pruned small-caliper Quercus bicolor and Quercus macrocarpa trees 6 weeks (20 June), 12 weeks (14 Aug.) and 18 weeks (25 Sept.) after transplanting during the growing season.

\begin{tabular}{lllll}
\hline \multirow{2}{*}{ Species } & Treatment & 20 June & 14 Aug. & 25 Sept. \\
\hline Q. bicolor & Control & $-0.25 \mathrm{a}^{\mathrm{z}}$ & $-0.25 \mathrm{a}$ & $-0.18 \mathrm{a}$ \\
\multirow{4}{*}{ Q. macrocarpa } & Root pruning & $-0.25 \mathrm{a}$ & $-0.22 \mathrm{a}$ & $-0.14 \mathrm{a}$ \\
& Control & $-0.35 \mathrm{~b}$ & $-0.25 \mathrm{a}$ & $-0.19 \mathrm{a}$ \\
& Root pruning & $-0.35 \mathrm{~b}$ & $-0.31 \mathrm{a}$ & $-0.21 \mathrm{a}$ \\
& & & & \\
Q. bicolor & Control & $-0.69 \mathrm{a}$ & $-0.70 \mathrm{a}$ & $-0.77 \mathrm{a}$ \\
& Root pruning & $-0.65 \mathrm{a}$ & $-0.58 \mathrm{a}$ & $-0.72 \mathrm{a}$ \\
Q. macrocarpa & Control & $-0.97 \mathrm{~b}$ & $-0.64 \mathrm{a}$ & $-0.93 \mathrm{~b}$ \\
& Root pruning & $-1.24 \mathrm{c}$ & $-0.86 \mathrm{a}$ & $-1.24 \mathrm{~b}$ \\
\hline
\end{tabular}

${ }^{\mathrm{z}}$ Significant differences among means within a column and response variables $\left(\Psi_{\text {pre }}, \Psi_{\text {mid }}\right)$ are indicated by different lowercase letters according to Tukey's honestly significant difference test $(P \leq 0.05)$.

summer $K_{\mathrm{P}}$ in root-pruned $Q$. bicolor). Control and root-pruned Q. bicolor had similar $K_{\mathrm{P}}$ in the fall.

Pre-dawn xylem water potential of $Q$. bicolor 6 weeks after transplanting was higher than that of $Q$. macrocarpa regardless of the treatment $[P=0.046$ (Table 3)]. Twelve and 18 weeks after transplanting, there was no difference in $\Psi_{\text {pre }}$ between the two species $(P=0.117$ for 12 weeks and $P=$ 0.328 for 18 weeks). Root pruning had no effect on $\Psi_{\text {pre }}$ on any measurement date. Midday xylem water potential was higher in $Q$. bicolor than $Q$. macrocarpa 6 weeks and 18 weeks after transplanting $(P<0.001$ for 6 weeks, $P=0.056$ for 12 weeks, and $P<0.001$ for 18 weeks). Six weeks after transplanting root pruning had no effect on $\Psi_{\text {mid }}$ in $Q$. bicolor but decreased $\Psi_{\text {mid }}$ of $Q$. macrocarpa $(P=0.750$ for $Q$. bicolor and $P=0.021$ for $Q$. macrocarpa).

Stem vulnerability curves, used to examine cavitation resistance of each species, showed $Q$. macrocarpa was more vulnerable than $Q$. bicolor at a xylem pressure of $-0.5 \mathrm{MPa}$ (Fig. 3). Average xylem pressure $P_{50}$ of $Q$. bicolor was $-0.80 \mathrm{MPa}$, whereas $P_{50}$ of $Q$. macrocarpa was $-0.48 \mathrm{MPa}(P=0.007)$.
When xylem pressure was more negative than $-1.0 \mathrm{MPa}$, cavitation resistance was similar between the two species. Both of the species lost more than $90 \%$ of conductivity when xylem pressure reached $-4 \mathrm{MPa}$.

LARGE-CALIPER TREES. All of the largecaliper $Q$. macrocarpa trees exhibited much less shoot growth and much smaller "scorched" new leaves compared with $Q$. bicolor regardless of the transplant timing.

In general, fine root $K_{\mathrm{S}}$ of large-caliper $Q$. bicolor trees was greater than Q. macrocarpa (Fig. 4A and C). Fall and spring transplanting decreased fine root $K_{\mathrm{S}}$ of $Q$. macrocarpa 6 months after transplanting (fall transplanting, $P=0.022$; spring transplanting, $P=$ $0.008)$. In contrast, fall transplanting had no effect on fine root $K_{\mathrm{S}}$ of $Q$. bicolor 6 months after transplanting, whereas spring transplanting increased fine root $K_{\mathrm{S}}$ of $Q$. bicolor 6 months after transplanting $(P<0.001)$.

In general, coarse root $K_{\mathrm{S}}$ of $Q$. bicolor was greater than $Q$. macrocarpa (Fig. 4B and D). Spring transplanting had no effect on coarse root $K_{\mathrm{S}}$ in either species 6 months after transplanting.

Six months after fall transplanting, fine root branching ratio $\left(R_{\mathrm{b}}\right)$ was higher in roots of large-caliper $Q$. bicolor trees than $Q$. macrocarpa [5.12 vs. 3.89, $P=0.004$ (Fig. 5B)]. Each fifthorder root in $Q$. bicolor had more first-order (root tips, $P=$ $0.005)$, second-order $(P=0.005)$, and third-order $(P=0.023)$ roots than in $Q$. macrocarpa (Fig. 5A). Differences in fine root branching resulted in that $Q$. bicolor has more fibrous fine root systems than $Q$. macrocarpa (Fig. 5C-D).

\section{Discussion}

Our results indicate that hydraulic conductance in fine roots is related to recovery of $Q$. bicolor and $Q$. macrocarpa after transplanting. In our experiments, stem diameter growth after transplanting was greater for small-caliper $Q$. bicolor trees than Q. macrocarpa. Fine root $K_{\mathrm{S}}$ in both species of small-caliper trees decreased $\approx 50 \%$ to $70 \%$ after a drying period of $3 \mathrm{~d}$ on the bench. Reduced $K_{\mathrm{S}}$ was most likely the result of water stressinduced embolisms during the drying process (Kavanagh and Zaerr, 1997). Compared with fine root $K_{\mathrm{S}}$ before transplanting, small-caliper $Q$. bicolor maintained similar $K_{\mathrm{S}} 6$ months after transplanting despite the severe loss in root biomass resulting from root pruning, whereas $K_{\mathrm{S}}$ in $Q$. macrocarpa dramatically decreased. Higher $K_{\mathrm{S}}$ in fine roots implies more sites for water uptake and transport to leaves, which increases turgor pressure and allows stomata to open (Trifilò et al., 2004), increases the rate of carbon gain, and therefore promotes faster recovery from transplant shock compared with a species with lower fine $\operatorname{root} K_{\mathrm{S}}$.

Others have reported that successful recovery of $K_{\mathrm{S}}$ in smallcaliper $Q$. bicolor trees is associated with fast root regeneration after transplanting (Harris et al., 2002). Maintaining a high $\Psi_{\text {pre }}$ after transplanting is essential for the rapid root regeneration of transplanted trees (Kaushal and Aussenac, 1989), which was the case for $Q$. bicolor in our experiments. Midday xylem water potential in root-pruned $Q$. macrocarpa was significantly lower than that in controls 6 weeks after transplanting, indicating root 


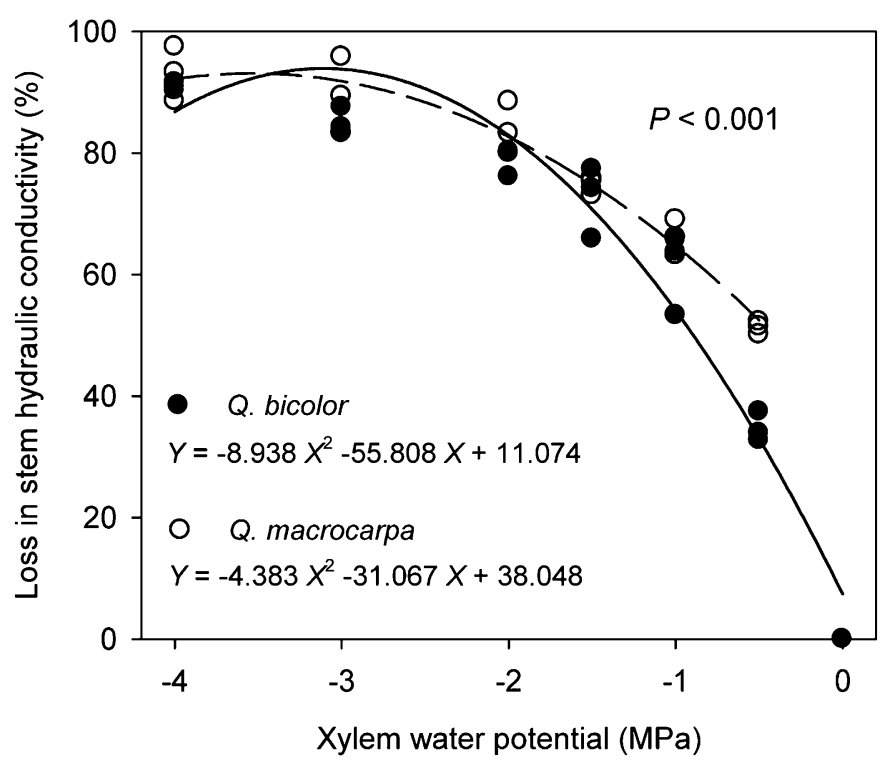

Fig. 3. Stem xylem vulnerability curves for small-caliper Quercus bicolor (solid dots) and Quercus macrocarpa (open dots) trees. Second-order polynomial models are indicated for each species. Probability value is indicated according to repeated-measures analysis of variance. pruning caused water deficits in Q. macrocarpa. However, both $\Psi_{\text {pre }}$ and $\Psi_{\text {mid }}$ in root-pruned $Q$. macrocarpa increased to a similar level as the controls 12 weeks after transplanting, implying that water status in $Q$. macrocarpa recovered from transplanting. In addition, estimations of $K_{\mathrm{P}}$ of the two species indicate that water status in both of the species fully recovered 12 weeks after transplanting.

Vulnerability curves indicate the vulnerability of woody plants to cavitation under drought (Tyree and Ewers, 1991). In our study, vulnerability curves of the two Quercus species showed that $P_{50}$ in $Q$. bicolor was more negative than that in $Q$. macrocarpa ( -0.80 vs. $-0.48 \mathrm{MPa})$. These results indicate that $Q$. bicolor was less vulnerable to mild water stress than $Q$. macrocarpa. Interestingly, when xylem pressure was more negative than $-1.0 \mathrm{MPa}$, cavitation resistance was similar between two species. Trees are probably more vulnerable to drought during transport before actual transplanting occurs (Harris and Bassuk, 1995). Growers may attempt to reduce desiccation of the roots in this stage of bare-root transplanting by immersing the root ball in water-retention hydrogel and/or wrapping the root ball with a moistened tarp. These techniques may reduce the level of water stress induced during the transporting stage and prevent large negative xylem pressures in the trees. However, we are unaware of any study that has empirically tested this effect. Moreover, the hydraulic safety margin [i.e., difference between minimum stem water potential under non-extreme conditions and $P_{50}$ (Meinzer et al., 2009)] of Q. macrocarpa is still too narrow to resist even mild levels of water stress. Species with more negative values of $P_{50}$ tend to have lower xylem recovery capacity once their stems have lost $50 \%$ of the conductivity (Ogasa et al., 2013). This suggests that inappropriate handling and transport of $Q$. bicolor trees by exposing them to severe drought before transplanting may diminish their post-transplant growth and survival.

Root system architecture, especially the number of lower-order roots, may play an important role in post-transplant recovery of trees. Six months after transplanting, large-caliper $Q$. bicolor trees had more fine-root branching than $Q$. macrocarpa. However, each fifthorder root had a similar number of fourth-order roots in both species. More lower-order roots in $Q$. bicolor indicates the trees had more root area than $Q$. macrocarpa, which would increase the contact between roots and soil and facilitate root access to water and nutrients in the soil. In our experiments, fine root $K_{\mathrm{S}}$ in $Q$. bicolor was greater than $Q$. macrocarpa. These results indicate that regeneration of more lower-order roots after transplanting in $Q$. bicolor could confer better 

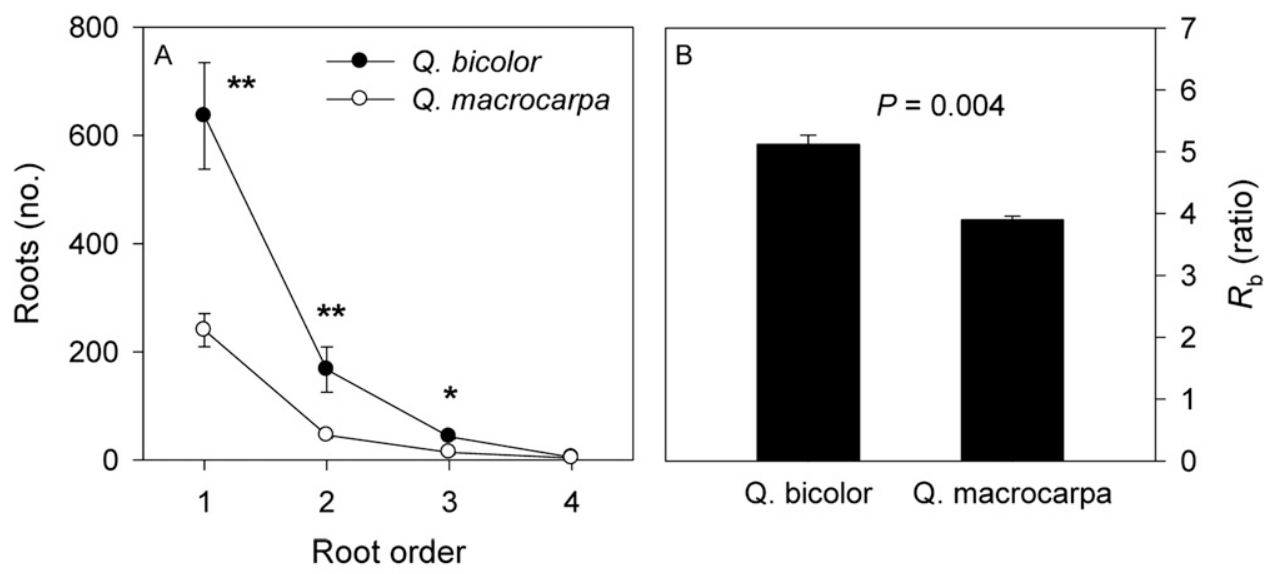

transplanting. For large-caliper $Q$. bicolor, fine root $K_{\mathrm{S}}$ in springtransplanted trees increased 6 months after transplanting, whereas fine root $K_{\mathrm{S}}$ in fall-transplanted trees did not change. This different response in fine root $K_{\mathrm{S}}$ to spring vs. fall transplanting could be related to the xylem anatomical characteristics of Quercus trees. Quercus is a ring-porous species that produces larger vessels in spring wood vs. summer wood. Therefore, they could restore hydraulic conductance by developing new xylem in the spring, which makes spring transplanting optimal (Struve, 2009). Similar $K_{\mathrm{S}}$ obtained in fall-transplanted $Q$. $b i$ color trees was likely a result of our measurement timing occurring before the development of new xylem in the spring. Failure to grow new roots in spring-transplanted $Q$. macrocarpa might be because carbohydrate reserves in the roots or other plant organs was less than that required for the metabolic processes involved in root regeneration (Guehl et al., 1993). Spring-transplanted trees require budbreak and root extension to begin simultaneously (Harris et al., 2002). Carbohydrate reserves would be further restricted if carbon assimilation capacity of a tree is

drought resistance to this species by increasing root hydraulic conductance and supplying more water for canopy development.

Transplant timing affects transplant success by influencing the potential for quick post-transplant root regeneration with its specific weather and light characteristics (Richardson-Calfee and Harris, 2005). Fine root $K_{\mathrm{S}}$ in root-pruned large-caliper $Q$. macrocarpa trees decreased after transplanting regardless of the transplant season. However, spring-transplanted $Q$. macrocarpa had a lower fine root $K_{\mathrm{S}}$ than fall-transplanted trees and root pruning caused a greater reduction in $K_{\mathrm{S}}$ in spring-transplanted trees. Actually, 6 months after spring transplanting, we could not find intact fine root branches from $Q$. macrocarpa trees. Failure to regenerate fine roots in the spring-transplanted trees may be the result of a time lag necessary in adjusting to the considerable injury and loss of roots from transplanting before resumption of root growth, as was seen in Quercus rubra trees in Richardson-Calfee et al. (2004). Similarly, Harris et al. (2002) reported that fall-transplanted bare-root Acer saccharum and $Q$. rubra trees developed new roots earlier and faster than spring-transplanted trees. Better root regeneration in these studies allowed successful post-transplant recovery, but in our study, minimal fine root regeneration in fall-transplanted $Q$. macrocarpa trees did not induce enough root hydraulic conductance to keep the trees from "transplant shock" in which the trees showed much less shoot growth and much smaller "scorched" new leaves.

Fine root $K_{\mathrm{S}}$ in large-caliper Quercus trees responded differently to spring and fall transplanting 6 months after largely compromised in transplanting. Furthermore, each species has their specific range of rhizosphere conditions that are most suitable for root regeneration (Richardson-Calfee and Harris, 2005), which could also lead to the difference in optimal transplant timing between $Q$. bicolor and $Q$. macrocarpa although both of them are ring-porous species.

Compared with $Q$. bicolor trees, $Q$. macrocarpa is often described as more difficult to transplant. However, in this study, all of the small-caliper $Q$. macrocarpa trees fully recovered after transplanting, whereas large-caliper $Q$. macrocarpa trees exhibited typical symptoms of transplant shock. This result is consistent with the previous observations that small-caliper trees survive better than large-caliper trees after transplanting (Gilman et al., 1998; Lauderdale et al., 1995; Watson, 2005). However, in our study, small- and large-caliper Quercus trees were grown in different conditions (greenhouse vs. field). The warm temperature and ample soil moisture in the greenhouse may have facilitated post-transplant recovery of small-caliper $Q$. macrocarpa: warmer soil temperature decreases the viscosity of water and thus increases root hydraulic conductance (Ritchie, 2003), which supplies more water for root regeneration and canopy development of small-caliper $Q$. macrocarpa after transplanting.

In conclusion, hydraulic conductance in fine roots is related to transplant recovery of two Quercus tree species after transplanting. Six months after transplanting, although none of the small-caliper trees suffered from visible signs of transplant shock, fine root $K_{\mathrm{S}}$ in root-pruned $Q$. bicolor was much higher 
than that in root-pruned $Q$. macrocarpa, resulting in larger stem growth in $Q$. bicolor. For large-caliper trees, failure in posttransplant recovery of $Q$. macrocarpa trees was the result of more vulnerability to transplant-induced mild water stress compared with $Q$. bicolor, failure in fine root regeneration, ultimately resulting in a large reduction in fine root hydraulic conductance. Optimal transplant timing is species-specific, probably depending on the intrinsic characteristic of the species such as xylem anatomy, carbohydrate reserves, and rhizosphere conditions.

\section{Literature Cited}

Alder, N., W. Pockman, J. Sperry, and S. Nuismer. 1997. Use of centrifugal force in the study of xylem cavitation. J. Expt. Bot. 48:665-674.

Buckstrup, M. and N. Bassuk. 2009. Creating the urban forest: The bare root method. Cornell Univ. Urban Hort. Inst., Ithaca, NY.

Comas, L., T. Bouma, and D. Eissenstat. 2002. Linking root traits to potential growth rate in six temperate tree species. Oecologia 132:34-43.

Cruiziat, P., H. Cochard, and T. Améglio. 2002. Hydraulic architecture of trees: Main concepts and results. Ann. For. Sci. 59:723-752.

Fitter, A.H. 1982. Morphometric analysis of root systems: Application of the technique and influence of soil fertility on root system development in two herbaceous species. Plant Cell Environ. 5:313-322.

Gilman, E.F., R.J. Black, and B. Dehgan. 1998. Irrigation volume and frequency and tree size affect establishment rate. J. Arboricult. 24:1-9.

Grossnickle, S.C. 1988. Planting stress in newly planted jack pine and white spruce. 1. Factors influencing water uptake. Tree Physiol. 4:71-83.

Guehl, J.M., A. Clement, P. Kaushal, and G. Aussenac. 1993. Planting stress, water status and non-structural carbohydrate concentrations in corsican pine seedlings. Tree Physiol. 12:173-183.

Harris, J.R. and N.L. Bassuk. 1995. Effect of drought and phenological stage at transplanting on root hydraulic conductivity, growth indices, and photosynthesis of turkish hazelnut. J. Environ. Hort. 13:11-14.

Harris, J.R., J. Fanelli, and P. Thrift. 2002. Transplant timing affects early root system regeneration of sugar maple and northern red oak. HortScience 37:984-987.

Kaushal, P. and G. Aussenac. 1989. Transplanting shock in corsican pine and cedar of atlas seedlings: Internal water deficits, growth and root regeneration. For. Ecol. Mgt. 27:29-40.

Kavanagh, K.L. and J.B. Zaerr. 1997. Xylem cavitation and loss of hydraulic conductance in western hemlock following planting. Tree Physiol. 17:59-63.

Lauderdale, D.M., C.H. Gilliam, D.J. Eakes, G. Keever, and A. Chappelka. 1995. Tree transplant size influences post-transplant growth, gas exchange, and leaf water potential of 'October Glory' red maple. J. Environ. Hort. 13:178-181.

Meinzer, F.C., D.M. Johnson, B. Lachenbruch, K.A. McCulloh, and D.R. Woodruff. 2009. Xylem hydraulic safety margins in woody plants: Coordination of stomatal control of xylem tension with hydraulic capacitance. Funct. Ecol. 23:922-930.

Ogasa, M., N.H. Miki, Y. Murakami, and K. Yoshikawa. 2013. Recovery performance in xylem hydraulic conductivity is correlated with cavitation resistance for temperate deciduous tree species. Tree Physiol. 33:335-344.

Pregitzer, K.S., J.L. DeForest, A.J. Burton, M.F. Allen, R.W. Ruess, and R.L. Hendrick. 2002. Fine root architecture of nine North American trees. Ecol. Monogr. 72:293-309.

Richardson-Calfee, L.E. and J.R. Harris. 2005. A review of the effects of transplant timing on landscape establishment of field-grown deciduous trees in temperate climates. HortTechnology 15:132-135.

Richardson-Calfee, L.E., J.R. Harris, and J.K. Fanelli. 2004. Seasonal effects of transplanting on northern red oak and willow oak. J. Environ. Hort. 22:75-79.

Ritchie, G.A. 2003. Root physiology and phenology: The key to transplanting success. National proceedings: Forest and conservation nursery associations 2002. U.S. Dept. Agr. For. Serv., Rocky Mountain Res. Sta., Ogden, UT Proc. RMRS-P-28:98-104.

Schultz, H.R. and M.A. Matthews. 1988. Resistance to water transport in shoots of Vitis vinifera L. Relation to growth at low water potential. Plant Physiol. 88:718-724.

Sperry, J.S., J.R. Donnelly, and M.T. Tyree. 1988. A method for measuring hydraulic conductivity and embolism in xylem. Plant Cell Environ. 11:35-40.

Sperry, J.S. and W.T. Pockman. 1993. Limitation of transpiration by hydraulic conductance and xylem cavitation in Betula occidentalis. Plant Cell Environ. 16:279-287.

Sperry, J.S. and N.Z. Saliendra. 1994. Intra- and inter-plant variation in xylem cavitation in Betula occidentalis. Plant Cell Environ. 17:1233-1241.

Sperry, J.S. and M.T. Tyree. 1990. Water-stress-induced xylem embolism in three species of conifers. Plant Cell Environ. 13:427436.

Struve, D.K. 2009. Tree establishment: A review of some of the factors affecting transplant survival and establishment. Arboricult. Urban Forest. 35:10-13.

Struve, D.K., L. Burchfield, and C. Maupin. 2000. Survival and growth of transplanted large- and small-caliper red oaks. J. Arboricult. 26:162-169.

Trifilò, P., F. Raimondo, A. Nardini, M.L. Gullo, and S. Salleo. 2004. Drought resistance of Ailanthus altissima: Root hydraulics and water relations. Tree Physiol. 24:107-114.

Tyree, M.T. and F.W. Ewers. 1991. The hydraulic architecture of trees and other woody plants. New Phytol. 119:345-360.

Tyree, M.T., S. Patiño, J. Bennink, and J. Alexander. 1995. Dynamic measurements of roots hydraulic conductance using a high-pressure flowmeter in the laboratory and field. J. Expt. Bot. 46:83-94.

Watson, G.W. 1985. Tree size affects root regeneration and top growth after transplanting. J. Arboricult. 11:37-40.

Watson, G.W. and E.B. Himelick. 1983. Root regeneration of shade trees following transplanting. J. Environ. Hort. 1:52-54.

Watson, W.T. 2005. Influence of tree size on transplant establishment and growth. HortTechnology 15:118-122. 